\title{
Hidradenitis Suppurativa Quality of Life (HiSQOL): creation and validation of the Polish language version
}

\author{
Piotr K. Krajewski ${ }^{1}$, Łukasz Matusiak ${ }^{1}$, Marta Szepietowska², Julia E. Rymaszewska², Gregor B.E Jemec ${ }^{3}$, Joslyn S. Kirby ${ }^{4 \#,}$ \\ Jacek C. Szepietowski ${ }^{1}$ \\ 'Department of Dermatology, Venereology and Allergology, Wroclaw Medical University, Wroclaw, Poland \\ ${ }^{2}$ Student Research Group of Experimental Dermatology, Department of Dermatology, Venereology and Allergology, Wroclaw Medical \\ University, Wroclaw, Poland \\ ${ }^{3}$ Department of Dermatology, Zealand University Hospital, Roskilde; Health Sciences Faculty, University of Copenhagen, Denmark \\ ${ }^{4}$ Department of Dermatology, Penn State Health Milton S. Hershey Medical Center, Hershey, PA, USA \\ \#European Reference Network for Rare and Complex Diseases of the Skin (ERN-Skin) member
}

Adv Dermatol Allergol 2021; XXXVIII (6): 967-972

DOI: https://doi.org/10.5114/ada.2020.97064

\begin{abstract}
Introduction: Hidradenitis suppurativa (HS) is a chronic, inflammatory and painful cutaneous disease which often has a negative influence on patients' quality of life. Dermatology-specific instruments, such as Dermatology Life Quality Index and Skindex, are commonly used to evaluate HS patients' quality of life. However, due to the lack of specific questions, these scales may not be adequate and may not reflect the real problem.

Aim: To translate and validate the Polish version of a newly created HS-specific questionnaire - Hidradenitis Suppurativa Quality of Life (HiSQOL).

Material and methods: A forward and backward translation was conducted from the original English version of the questionnaire to Polish language according to international standards. The validation was performed on a group of 30 patients suffering from HS, who completed the questionnaire twice with a 4-5 days' interval.

Results: The Polish version of HiSQOL questionnaire showed a very good internal consistency (Cronbach $\alpha$ coefficient was 0.96 for total score). Excellent reproducibility with the intraclass correlation coefficient (ICC) of 0.97 was demonstrated.

Conclusions: The Polish version of HiSQOL questionnaire has high internal reliability, validity and reproducibility. It can be used as a tool to assess health-related quality of life in the patients suffering from hidradenitis suppurativa.

Key words: hidradenitis suppurativa, quality of life, questionnaire.
\end{abstract}

\section{Introduction}

Hidradenitis suppurativa (HS) is a painful chronic, multifactorial and progressive inflammatory cutaneous disease of the pilosebaceous unit. It is characterized by the formation of inflamed nodules, abscesses, tunnels and scars. It predominantly affects intertriginous areas of the body, like axillae, groins, buttocks and sub-mammary region [1]. Due to the pain, discharge, foul smell and associated pruritus, HS has documented negative influence on patients' health related quality of life (HRQOL) [2, 3]. Moreover, the disease often has correlated severe socioeconomic consequences, higher incidence of depression, fear of stigmatization, and suicide [4-7].

Numerous dermatologic instruments have been developed to evaluate impact of the disease on patients' quality of life. The most frequently used are dermatologyspecific questionnaires, like Dermatology Life Quality Index (DLQI) [8]. However, there are also multiple diseasespecific questionnaires. These are used for assessment of the quality of life related to, among others, psoriasis (Psoriasis Disability Index) [9], Acne (Cardiff Acne Disability Index) [10] or dermatitis (Infants' Dermatitis Quality of Life index) [11]. Dermatology-specific instruments, such as DLQI [8] and Skindex [12], were commonly used to evaluate HS patients' quality of life. However, due to the lack of specific questions, these scales may not be adequate and may not reflect the real problem [13].

Hidradenitis Suppurativa Quality of Life (HiSQOL) is a new, 17-item questionnaire developed in 2019 by Thorlacius et al. [13] by combined effort of Danish and

Address for correspondence: Prof. Jacek C Szepietowski MD, PhD, Department of Dermatology, Venereology and Allergology, Wroclaw Medical University, 1 Chalubinskiego St, 50-368 Wroclaw, Poland, phone: +48 601534 853, e-mail: jacek.szepietowski@umed.wroc.pl Received: 15.05 .2020 , accepted: 6.06.2020. 
American experts. It evaluates the impact of HS on the quality of life, patients' symptoms and emotions in the last 7 days.

\section{Aim}

The aim of this study was to translate and to validate the Polish language version of HiSQOL questionnaire. This would enable the use of HiSQOL in both clinical practice and research by Polish-speaking clinicians.

\section{Material and methods}

The Polish version of the HiSQOL questionnaire was translated and validated according to international standards [14]. The permission to translate the questionnaire was provided by the copyright holders.

\section{Translation and validation}

Firstly, the original English version of HiSQOL questionnaire was translated into Polish language by two independent translators (MS, JR). Then, the translated versions were compared in terms of inconsistencies by a third consultant, a bilingual expert in the field (JCS). After that, the unified version was created. Subsequently, the backtranslation from the Polish version was conducted ( $Ł M)$. The translator was not familiar with the original version of HiSQOL questionnaire. Afterwards, the back translation was sent to members of the team who created the original questionnaire (JSK, GBEJ). Minor changes were introduced according to the authors' recommendations. Finally, the Polish version of the HiSQOL questionnaire was created.

After the translation process, the validation was performed. The questionnaire was tested on a group of 30 people. All of the interviewed patients were diagnosed with HS by a specialist. They were asked to complete the questionnaire twice with a 4-5 days' interval. This period was considered sufficiently long to prevent the patients from remembering previous answers, as well as sufficiently short to prevent any significant changes in the clinical severity of HS.

\section{Statistical analysis}

The statistical analysis of the obtained results was performed with the use of IBM SPSS Statistics v. 26 (SPSS INC., Chicago, USA) software. The internal consistency of the questionnaire was evaluated with Cronbach $\alpha$ coefficient. The correlation between the responses from a single completion to each individual question, as well as to the total score, was established with Spearman correlation test. It is believed that to prove that the questionnaire is internally consistent, the Cronbach $\alpha$ coefficient should be at least 0.7, while the values above 0.90 stand for very good internal consistency [15]. The questionnaire reproducibility (test-retest reliability) was assessed by comparison of the two responses of each patient with the use of intraclass correlation coefficient (ICC). To indicate adequate reproducibility of the questionnaire, ICC, similarly to Cronbach $\alpha$ coefficient, should also be at least 0.7 [16]. The correlation between each item from the first and the second completion was analyzed. Moreover, answers to each question from the first and the second completion were compared using Wilcoxon signed-rank test in a search for significant differences. A 2 -sided $p$-value $\leq 0.05$ was considered to be statistically significant.

\section{Results}

The assessment of internal consistency of the Polish language version of HiSQOL showed that the different items from the questionnaire were correlated with one another. Cronbach $\alpha$ coefficient value for the HiSQOL total score was at 0.96, which indicated an excellent internal consistency of the translated questionnaire. Moreover, each of three subscales also had very good internal consistency with the Cronbach $\alpha$ coefficient values of 0.94 for activities-adaptations subscale, 0.87 for psychosocial subscale and 0.89 for symptoms subscale. Additionally, statistically significant, positive correlations were found between each question and the HiSQOL total score (Table 1). The Spearman correlation coefficient of each item and the total score of the scale was 0.500 to 0.934 , and the Spearman correlation coefficient of each item was 0.224 to 0.654 (Table 1). Only one of the questions (question 16) did not statistically correlate with the rest of them, nevertheless, its correlation with total HiSQOL score was statistically significant $(r=0.500, p<0.001)$. The above-presented results showed an excellent convergent validity of the translated version of the instrument.

The reproducibility of the studied questionnaire was determined using ICC and assessed as 0.966 for the whole HiSQOL. Furthermore, no statistically significant differences were found between the answers for each question obtained after completing the questionnaire twice (4-5 days' interval) (Table 2). Correlation coefficient assessed with Spearman test, between the answers obtained in the first and the second survey were analyzed. A statistically significant, positive correlations were found for each pair of answers (data not shown).

The Polish validated version of HiSQOL is contained in Appendix 1.

\section{Discussion}

Hidradenitis suppurativa is a burdensome disease with huge influence on patients' health-related quality of life. Due to the troublesome, often embarrassing symptoms, patients feel stigmatized and the disease frequently leads to depression, severe socio-economic problems and even suicide [4-7]. Because of this psychological impact, 


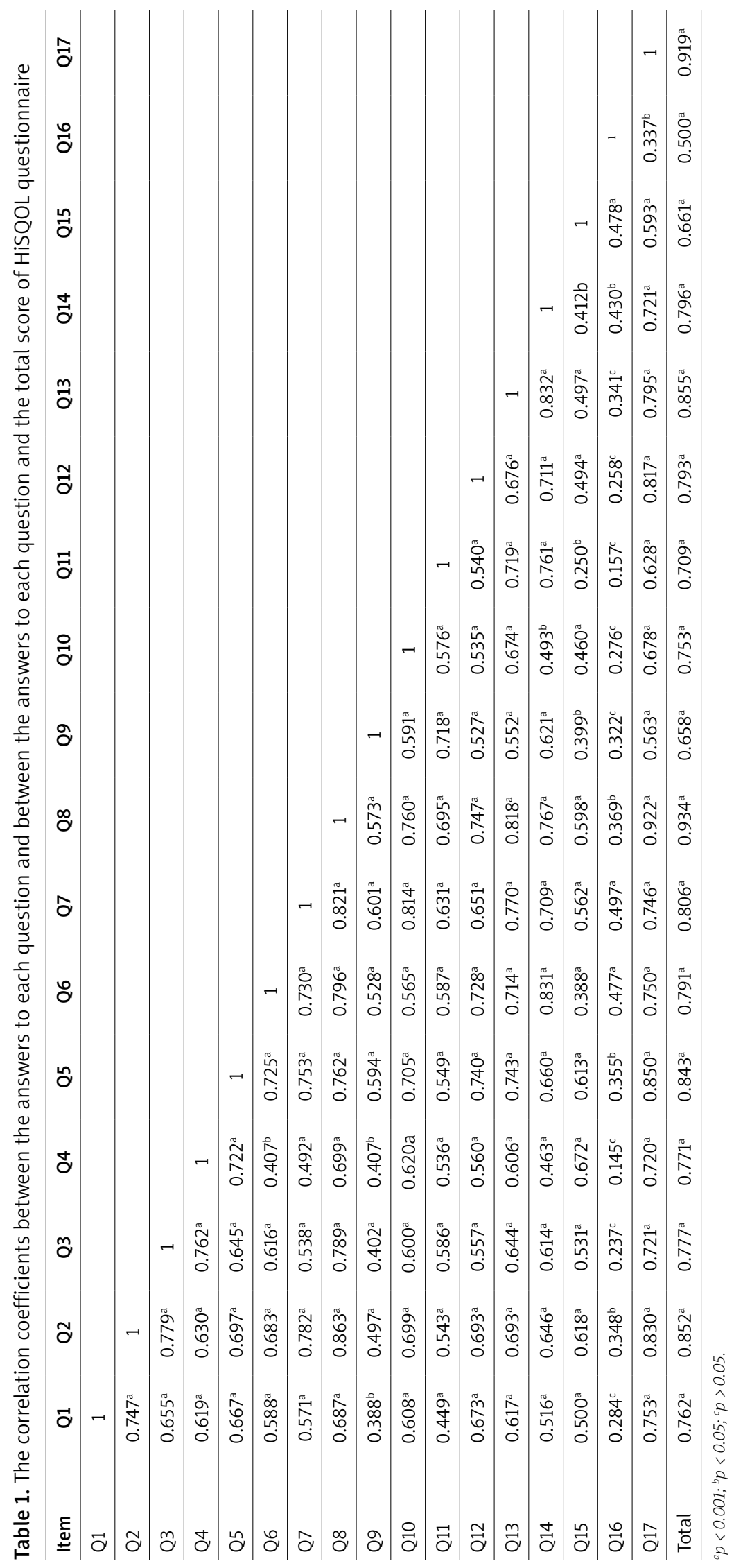


Table 2. Reproducibility of the results

\begin{tabular}{lccc}
\hline Item & $\begin{array}{c}1^{\text {st }} \\
\text { assessment } \\
\text { (points) }\end{array}$ & $\begin{array}{c}2^{\text {nd }} \text { assessment } \\
\text { (points) }\end{array}$ & $\boldsymbol{P}$-value \\
\hline Q1 & $1.33 \pm 1.15$ & $1.4 \pm 1.3$ & 0.637 \\
\hline Q2 & $1.93 \pm 1.52$ & $2.03 \pm 1.4$ & 0.584 \\
\hline Q3 & $1 \pm 0.98$ & $1.07 \pm 0.94$ & 0.414 \\
\hline Q4 & $1.2 \pm 1.21$ & $1.27 \pm 1.20$ & 0.493 \\
\hline Q5 & $1.53 \pm 1.33$ & $1.6 \pm 1.3$ & 0.796 \\
\hline Q6 & $1.33 \pm 1.02$ & $1.47 \pm 1.14$ & 0.206 \\
\hline Q7 & $2.2 \pm 1.44$ & $2.13 \pm 1.31$ & 0.527 \\
\hline Q8 & $1.83 \pm 1.18$ & $1.7 \pm 1.21$ & 0.285 \\
\hline Q9 & $1.77 \pm 1.17$ & $1.8 \pm 1.16$ & 0.926 \\
\hline Q10 & $2.2 \pm 1.35$ & $2.2 \pm 1.32$ & 1 \\
\hline Q11 & $1.77 \pm 1.25$ & $1.73 \pm 1.08$ & 0.705 \\
\hline Q12 & $1.63 \pm 1.19$ & $1.5 \pm 1.20$ & 0.206 \\
\hline Q13 & $1.8 \pm 1.24$ & $1.77 \pm 1.28$ & 0.851 \\
\hline Q14 & $1.7 \pm 1.26$ & $1.67 \pm 1.32$ & 0.666 \\
\hline Q15 & $1.67 \pm 1.63$ & $1.6 \pm 1.57$ & 0.317 \\
\hline Q16 & $1.33 \pm 1.43$ & $1.43 \pm 1.33$ & 0.889 \\
\hline Q17 & $1.4 \pm 1.3$ & $1.2 \pm 1.27$ & 0.132 \\
\hline Total score & $27.63 \pm 17.19$ & $27.57 \pm 16.89$ & 0.602 \\
\hline & & &
\end{tabular}

the psychometric assessment plays a significant role in the diagnosis and the treatment choice in these patients. The HiSQOL is a new, HS-specific, 17-item questionnaire divided into 3 subscales: activities-adaptations, psychosocial and symptoms. In comparison to the existing dermatology-specific instruments, HiSQOL identifies all the important aspects for HS patients, which are often absent in the above-mentioned questionnaires (e.g. pus drainage or odor). Besides HiSQOL, there are two HS-specific questionnaires. Hidradenitis Suppurativa Burden Of Disease (HSBOD) [17], a 19-item instrument with answers on visual analog scale, and Hidradenitis Suppurativa Quality of Life (HS-QoL) [18], a questionnaire with 44 items and a 6-month recall period. Nevertheless, HiSQOL is different from existing instruments. It is the only one for which full psychometric evaluation was performed and published. Moreover, it consists of three subscales which may be used independently or to generate a total score.

This study describes the process of development and validation of the Polish language version of HiSQOL questionnaire. The analysis of internal consistency was performed on the basis of the results obtained after a single completion of the questionnaire. Statistically significant, positive correlation was found between each question and HiSQOL total score. Additionally, the internal consistency was at a very high level, with Cronbach $\alpha$ value of 0.96 for HiSQOL total score and 0.87-0.94 for three subscales. Our results are similar to those obtained by the authors of the original version of questionnaire (0.94 for total score, 0.81-0.88 for subscales). The reproducibility of the instrument was evaluated with the use of ICC. We achieved an excellent reproducibility with the value of ICC of 0.97 for the whole questionnaire, which was actually even higher than in the original version (0.90) [19].

To the best of our knowledge, this is the first translation and validation of HiSQOL questionnaire from English to another language. Similar projects were conducted with other instruments. Among them, our group [20, 21] successfully created and validated Polish and Arabic versions of 6-item Stigmatization Scale and 33-item Feelings of Stigmatization Questionnaire. In both of them, we achieved the Cronbach $\alpha$ value of 0.94 for the Polish and 0.89 for the Arabic version [20, 21]. Moreover, Szepietowski et al. [22] also performed a translation and validation of Dermatology Life Quality Index (DLQI) and obtained very good results with Cronbach efficient value of 0.9.

The recently developed Polish language HiSQOL questionnaire showed a high internal consistency and a good reproducibility. Our results indicate, that this version of the instrument may be used for assessment of HRQOL, both in everyday patients care, as well as in the research programs. Moreover, in the presented paper we have shown a detailed and appropriate way of translation and validation of foreign language questionnaires. It needs to be emphasized that proper validation should be conducted for every questionnaire used in clinical practice.

\section{Conflict of interest}

The authors declare no conflict of interest.

\section{References}

1. Zouboulis CC, Desai N, Emtestam L, et al. European S1 guideline for the treatment of hidradenitis suppurativa/acne inversa. J Eur Acad Dermatol Venereol 2015; 29: 619-44.

2. Cuenca-Barrales C, Molina-Leyva A. Risk factors of sexual dysfunction in patients with hidradenitis suppurativa: a cross-sectional study. Dermatology 2020; 236: 37-45.

3. Matusiak L, Bieniek A, Szepietowski JC. Psychophysical aspects of hidradenitis suppurativa. Acta Derm Venereol 2010; 90: 264-8.

4. Vazquez BG, Alikhan A, Weaver AL, et al. Incidence of hidradenitis suppurativa and associated factors: a populationbased study of Olmsted County, Minnesota. J Invest Dermatol 2013; 133: 97-103.

5. Matusiak L, Bieniek A, Szepietowski JC. Hidradenitis suppurativa markedly decreases quality of life and professional activity. J Am Acad Dermatol 2010; 62: 706-8.

6. Theut Riis P, Thorlacius L, Knudsen List E, Jemec GBE. A pilot study of unemployment in patients with hidradenitis suppurativa in Denmark. Br J Dermatol 2017; 176: 1083-5.

7. Thorlacius L, Cohen AD, Gislason GH, et al. Increased suicide risk in patients with hidradenitis suppurativa. J Invest Dermatol 2018; 138: 52-7.

8. Finlay AY, Khan GK. Dermatology Life Quality Index (DLQI): a simple practical measure for routine clinical use. Clin Exp Dermatol 1994; 19: 210-6. 
9. Finlay AY, Coles EC. The effect of severe psoriasis on the quality of life of 369 patients. Br J Dermatol 1995; 132: 236-44.

10. Motley RJ, Finlay AY. Practical use of a disability index in the routine management of acne. Clin Exp Dermatol 1992; 17: 1-3.

11. Lewis-Jones MS, Finlay AY, Dykes PJ. The Infants' Dermatitis Quality of Life Index. Br J Dermatol 2001; 144: 104-10.

12. Chren MM, Lasek RJ, Flocke SA, Zyzanski SJ. Improved discriminative and evaluative capability of a refined version of Skindex, a quality-of-life instrument for patients with skin diseases. Arch Dermatol 1997; 133: 1433-40.

13. Thorlacius L, Esmann S, Miller I, et al. Development of HiSQOL: a hidradenitis suppurativa-specific quality of life instrument. Skin Appendage Disord 2019; 5: 221-9.

14. Acquadro C, Conway K, Hareendran A, et al. Literature review of methods to translate health-related quality of life questionnaires for use in multinational clinical trials. Value Health 2008; 11: 509-21.

15. Cronbach LJ. Coefficient alpha and the internal structure of tests. Psychometrika 1951; 16: 297-334.

16. Shrout PE, Fleiss JL. Intraclass correlations: uses in assessing rater reliability. Psychol Bull 1979; 86: 420-8.

17. Pinard J, Vleugels RA, Joyce C, et al. Hidradenitis suppurativa burden of disease tool: pilot testing of a disease-specific quality of life questionnaire. J Am Acad Dermatol 2018; 78: 215-7.

18. Sisic M, Kirby JS, Boyal S, et al. Development of a quality-oflife measure for hidradenitis suppurativa. J Cutan Med Surg 2017; 21: 152-5.

19. Kirby JS, Thorlacius L, Villumsen B, et al. The Hidradenitis Suppurativa Quality of Life (HiSQOL) score: development and validation of a measure for clinical trials. Br J Dermatol 2019; 10.1111/bjd.18692, doi:10.1111/bjd.18692.

20. Hrehorów E, Szepietowski J, Reich A, et al. Instruments for stigmatization evaluation in patients suffering from psoriasis: Polish language versions. Clin Dermatol 2006; 8: 253-8.

21. Dimitrov D, Matusiak L, Evers A, et al. Arabic language skinrelated stigmatization instruments: translation and validation process. Adv Clin Exp Med 2019; 28: 825-32.

22. Szepietowski J, Salomon J, Finlay AY, et al. Dermatology Life Quality Index (DLQI): Polish vesion. Dermatol Klin 2004; 6: 63-70. 


\section{Appendix 1}

Ten kwestionariusz jest zaprojektowany do pomiaru, jaki wpływ na Panią (Pana) ma hidradenitis suppurativa (HS) - trądzik odwrócony

PROSZĘ ZAPOZNAĆ SIĘ Z PONIŻSZĄ INSTRUKCJĄ:

Ważne jest, aby:

1) rozważyć wpływ HS na Pani (Pana) życie w ciągu ostatnich 7 dni.

2) myśleć jedynie o HS, nie o innych dolegliwościach.

3) w każdej linijce proszę wybrać jedną najlepszą (najbardziej trafną) odpowiedź.

Dla każdego punktu proszę wybrać jedną najlepszą (najbardziej trafną) odpowiedź.

\begin{tabular}{|c|c|c|c|c|c|c|}
\hline $\begin{array}{l}\text { W ciągu ostatnich } \underline{7 \text { dni, jak bardzo HS }} \\
\text { sprawiat problemy z: }\end{array}$ & $\begin{array}{c}\text { Niemożliwe } \\
\text { do wykonania } \\
\text { z powodu HS }\end{array}$ & Ekstremalnie & Bardzo & Umiarkowanie & Nieznacznie & Wcale \\
\hline 1) chodzeniem (nie dla ćwiczeń) & [ ] & & & & & \\
\hline $\begin{array}{l}\text { 2) ćwiczeniem (np. pływaniem, joggingiem, } \\
\text { jazdą na rowerze, jogą, aerobikiem) }\end{array}$ & [ ] & & & & & \\
\hline \multicolumn{7}{|l|}{ 3) snem } \\
\hline \multicolumn{7}{|l|}{ 4) myciem się } \\
\hline \multicolumn{7}{|l|}{ 5) ubieraniem się } \\
\hline \multicolumn{7}{|l|}{ 6) koncentracją } \\
\hline \multicolumn{2}{|c|}{$\begin{array}{l}\text { W ciągu ostatnich } 7 \text { dni, jak obecne lub potencjalnie } \\
\text { nowe zmiany HS wpływały na: }\end{array}$} & Ekstremalnie & Bardzo & Umiarkowanie & Nieznacznie & Wcale \\
\hline \multicolumn{7}{|l|}{ 7) wybór ubioru, aby uniknąć dyskomfortu } \\
\hline \multicolumn{2}{|c|}{ W ciągu ostatnich 7 dni, jak bardzo dokuczliwy byt: } & Ekstremalnie & Bardzo & Umiarkowanie & Nieznacznie & Wcale \\
\hline \multicolumn{7}{|l|}{ 8) ból } \\
\hline \multicolumn{7}{|l|}{ 9) świąd } \\
\hline \multicolumn{7}{|l|}{ 10) drenaż (sączenie) } \\
\hline 11) nieprzyjemny zapach & & & & & & \\
\hline
\end{tabular}

W ciągu ostatnich 7 dni, jak bardzo HS powodowat

Ekstremalnie Bardzo Umiarkowanie Nieznacznie Wcale odczucie:

\begin{tabular}{l}
\hline 12) przygnębienia lub depresji \\
\hline 13) zakłopotania \\
\hline 14) niepokoju lub nerwowości \\
\hline
\end{tabular}

\begin{tabular}{|c|c|c|c|c|c|c|c|}
\hline \multicolumn{3}{|c|}{ W ciągu ostatnich $\underline{7 \text { dni }}$, jak bardzo HS: } & Ekstremalnie & Bardzo & Umiarkowanie & Nieznacznie & Wcale \\
\hline $\begin{array}{l}\text { 15) utrudniał aktywność } \\
\text { seksualną }\end{array}$ & $\begin{array}{l}\text { Nie jestem } \\
\text { aktywny } \\
\text { seksualnie } \\
\text { [ ] }\end{array}$ & $\begin{array}{l}\text { Niemożliwe } \\
\text { do wykonania } \\
\text { z powodu HS } \\
\text { [ ] }\end{array}$ & & & & & \\
\hline
\end{tabular}

16) wpływat na pragnienie

aktywności seksualnej

\begin{tabular}{|c|c|c|c|c|c|c|c|}
\hline \multicolumn{3}{|c|}{ W ciągu ostatnich 7 dni, jak bardzo HS: } & \multirow[t]{2}{*}{ Ekstremalnie } & \multirow[t]{2}{*}{ Bardzo } & \multirow[t]{2}{*}{ Umiarkowanie } & \multirow[t]{2}{*}{ Nieznacznie } & \multirow[t]{2}{*}{ Wcale } \\
\hline $\begin{array}{l}\text { 17) wptynąt na zdolność do } \\
\text { pracy lub nauki }\end{array}$ & $\begin{array}{l}\text { Nie pracuję i } \\
\text { nie studiuję } \\
\text { [ ] }\end{array}$ & $\begin{array}{l}\text { Niemożliwe } \\
\text { do wykonania } \\
\text { z powodu HS } \\
\text { [ ] }\end{array}$ & & & & & \\
\hline
\end{tabular}

